\title{
FIRST PROPOSAL OF SEED REGIONS FOR FRANKINCENSE TREES (BOSWELLIA SPP.) ON SOCOTRA ISLAND
}

\author{
LVONČÍK SMUEL ${ }^{1}$, MADĚRA PETR ${ }^{1}$, VOLAŘÍK DANIEL ${ }^{1}$, VRŠKOVÝ BORIS ${ }^{2}$, \\ HABROVÁ HANA ${ }^{1}$
}

\begin{abstract}
${ }^{1}$ Mendel University in Brno, Faculty of Forestry and Wood technology, Department of Forest Botany, Dendrology and Geobiocoenology, Zemědělská 3, 61300 Brno, Czech Republic, email:lvonca@ seznam.cz.

${ }^{2}$ Dudvážská 39, 82107 Bratislava, Slovak Republic
\end{abstract}

Received: $17^{\text {th }}$ March 2014, Accepted: $18^{\text {th }}$ April 2014

\begin{abstract}
The landscape differentiation on seed regions is used in the Czech forestry industry for purposes of seed transfers. The seed regions are created for main commercial tree species and the rules for transfer among these regions are described. The geobiocoenological landscape differentiation and differences among tree species populations were used as main approaches. The same principle is used for Boswellia seed regions differentiation on Socotra island. Eight species of Boswellia genus were determined on the island, all species being endemic. The differentiation is based on Boswellia populations field survey. All populations were described in morphological signs. The vegetation zones and geomorphological differentiation were also taken into account. The result is a map of seed regions for every Boswellia species on Socotra island presented in the article.
\end{abstract}

Key words: Boswellia, Socotra, Seed regions, Biodiversity,

\section{INTRODUCTION}

The vegetation of Socotra island is no doubt one of the most interesting and specific ones in the world (Brown \& Mies, 2012; Cheung \& Devantier, 2006). Due to an extreme heterogeneity of Socotra vegetation, it is considered, without any exaggeration and from many points of view, to be islands on an island; classical taxonomic approaches deal with a variety of problems, especially with the study of lower taxons and populations (Batelka, 2013).

In the past, the Socotra island was poorly accessible due to its geographical and political isolation. The conditions for research activities improved after the eastern bloc had collapsed, nevertheless, a lot of information is still missing. In the course of a number of large-scale pilot field surveys (Miller et al., 2004; Kilian \&Hein, 2006; Brown \& Mies, 2012) basic information about local flora was obtained. For most species a recent area and basic ecological requirements are at least partially known, however, actual level of knowledge is hardly sufficient for an effective ladscape management and protectionist measures (Scholte et al., 2010). 
The above-mentioned heterogeneity and the long-term isolation allowed the evolution and survival of more than 300 species of endemic plants (Brown \& Mies, 2012). The local endemic species can be classified into two categories commonly used - the paleoendemic species and the neoendemic species. The paleoendemics represent Tertiary or even older vegetation relics, having a relationship with a wide Paleotropis and Holoarktis areas. The paleoendemic species have, with a few exceptions, a clear taxonomic classification, since they are morphologically settled and with strong reproductive barriers (Kruckeberg \& Rabinowitz, 1985); the best known example on Socotra is the Dragon blood tree (Dracaena cinnabari).

On the other hand, a number of groups of species have relatively young secondary development centers, in which the neoendemical taxons originate, often vaguely classified. Young taxons are characteristic by poorly developed reproductive barriers (Kruckeberg \& Rabinowitz, 1985). Seven endemic species of Boswellia genus are a great example of this (Attore et al., 2011; Daly et al., 2011; Weeks et al., 2005). Intraspecific taxonomic studies indicate that some separated populations, or even individual specimens, markedly differ from each other (Eslamieh, 2011; Miller et al., 2004), being therefore largely unique.

\section{Why Rescue Plans?}

Focusing on the age structure of populations, from published sources (Attore et al., 2011) as well as from the field observation itself, there is an evident complete absence, or very rare occurence, of young and juvenile specimens of most Boswellia species. The reasons of insufficient regeneration are commonly known and mostly immediately apparent. These include especially the growing influence of grazing, combined with changes in the farming and growth of the human population on the island (Van Damme \& Banfield, 2011). Moreover, a change in climate, whether global or local, plays its certain role as well, and it is caused by an extensive disruption of vegetative cover (Scholte \& De Geest, 2010; Attore et al., 2007).

The absence of regeneration is exceptionally striking in the species growing in accessible locations (B. ameero, B. elongata, B. socotrana, B. dioscoridis). In regard to the species growing in rock crevices on the cliffs (B. bullata, B. popoviana, B. nana), at least a partial regeneration occures, due to an eliminating influence of the grazing (Attore et al., 2011).

\section{Rescue and support plans and their possible side effect}

In previous years, the island ran several projects aimed at the protection and plantation of autochthonous tree species (Habrová \& Němec, 2013; Habrová, 2012). However, a central coordination and a continuity of the projects, that would ensure a better efficiency of spent resources, is missing (Pietsch \& Banfield, 2013). A common problem is also the lack of information about the ecology and population dynamics of most of Socotra's plant species.

The rescue plans dedicated to the reproduction of the Boswellia population on Socotra, do not take into account the above-mentioned heterogeneity and uniqueness of the separated populations, and the plant material is distributed freely around the island. Hereat, a forethoughtless mixing of plants from different populations may cause an undesirable hybridisation and a loss of valuable biodiversity. Similarly, the expansion of the areas of individual species may lead to an undesirable interspecific hybridisation in the future. Cases of intentional, as well as autogenous, interspecific hybridization within the frame of Boswellia genus are already known, including continental and Socotran species (Eslamieh, 2011; Miller et al., 2004). When trees are planted, it is necessary to proceed very carefully and minimise all possible risks. 


\section{Options of artificial reproduction}

Rock species $B$. bullata, $B$. popoviana, $B$. nana and $B$. dioscoridis have very limited options of artificial reproduction. Therefore, the rescue plans activities should focus primarily on the prevention of loss of genetic variability and the creation of gene banks, for the case of devastation of localities as a result of unexpected disasters.

Regarding the species growing in open soil, specifically $B$. amaero, B. elongata, and $B$. socotrana, the options for reproduction are wider. For example, an effective alternative is the adaptation and implementation of the rules of forest reproduction, successfully used in the Czech Republic (MZe, 1996), and applied to Socotra.

Specific concepts for rules and procedures of reproduction of Boswellia populations are closely described in this article, taking into account maximal efforts to maintain the intraspecific diversity. The main contribution is the allocation of seed areas, within the frame of which the transplantation of Boswellia seedlings would not be a risk to loss of biodiversity. Also, a simple system of seedlings tagging in forest nurseries and gardens is listed. This will allow fast identification of the origin of seedlings, which is indispensable for the streamlining and controllability of nursery works.

\section{MATERIALS AND METHODS}

Initially, we extracted all known localities for all the species of Boswellias from Socotra. During the years 2012 and 2013 those localities were visited and, with the help of resident guides, several previously unpublished localities/individual occurences were discovered. Five individuals were localised using GPS on every habitat visited, while at unaccessible localities only one individual was localised. If there were three randomly selected leaves present, inflorescence and infructescence of localised individuals were photographically documented in detail for further morphometric measurements. Each photograph was accompained with a scale.

After that, morphological features captured in the photos were analysed. Specifically, the length and width of leaves or leaf segments in pinnate leaves, the shape of the leaf edges, leaf color, flower color, number of flowers in inflorescence and number of seeds in the fruit we observed. Morphological features were assessed for each species and strikingly different individuals were identified as morphotypes.

In the second step, maps were used to identify potential distribution areas of Bosweillia species (Attore et al., 2011), orographic regions of Socotra (Culek \& Král, 2004) biogeographical regions of Socotra, and localities of Boswellia occurences known from literature and from our field survey (Culek, 2004). After consultation with the authors of the map of biogeographical regions of Socotra, a small enhancement of the map was made. Specifically, orographic regions 23 and 24 were moved from western plais biogeographical region to the biogeographical region of Southern plains, becouse the biogeographical regions were allocated on the basis of boundaries of the areas of a large number of species; however, in the case of Boswellia, this limit seems illogical, especially after discovering a residual population of B.amaero and B.elongata in the aforementioned orographic regions.

Then, separately for each Boswellia species, orographic regions that at least partially overlapped with the potential or actual occurence of particular Boswellia species, were selected. These orographic regions were merged into groups according to the overlap with the biogeographical regions (Culek, 2004). The resulting groups of orographic regions are further referred to as seed areas 
The affiliation of individuals to the defined morphotypes was color-coded in the map. The groups of orographic regions with prevalent occurence of one morphotype were subsequently classified as seed sub-regions. All sub-areas were denoted, even the locations of occurence of the populations geographically isolated from the ramaining seed areas.

In addition, orographic regions without recently proven occurence of Boswellias, but fulfilling the other above-mentioned criteria (at least the overlapping potential area), are denoted as seed areas. Seed areas without recent occurence are mentioned in the results chapter.

With regard to the B. nana and B. bullata species, for which no models of potential areas were published, only the orographic regions with a occurence verified during our field research were denoted as seed areas.

\section{RESUlts}

More morphotypes were recognised by B. socotrana, B.ameero, B. popoviana, and $B$. elongata. Populations of $B$. dioscoridis and B.bullata are morphologicaly homogenous. On the contrary to other authors, we also evaluated the population of $B$. nana as homogeneous. This discrepancy is probably due to the small number of $B$. nana samples (only seven).

\section{Allocation of the seed areas}

Based on the method described above, on Socotra Island a total of 19 seed areas and 8 sub-areas were identified. The position of relevant individuals, localised using GPS during field monitoring, was demonstrated by points in the map (Fig. 1- 7).

\section{Fig. 1: Map of Boswellia ameero seed areas}

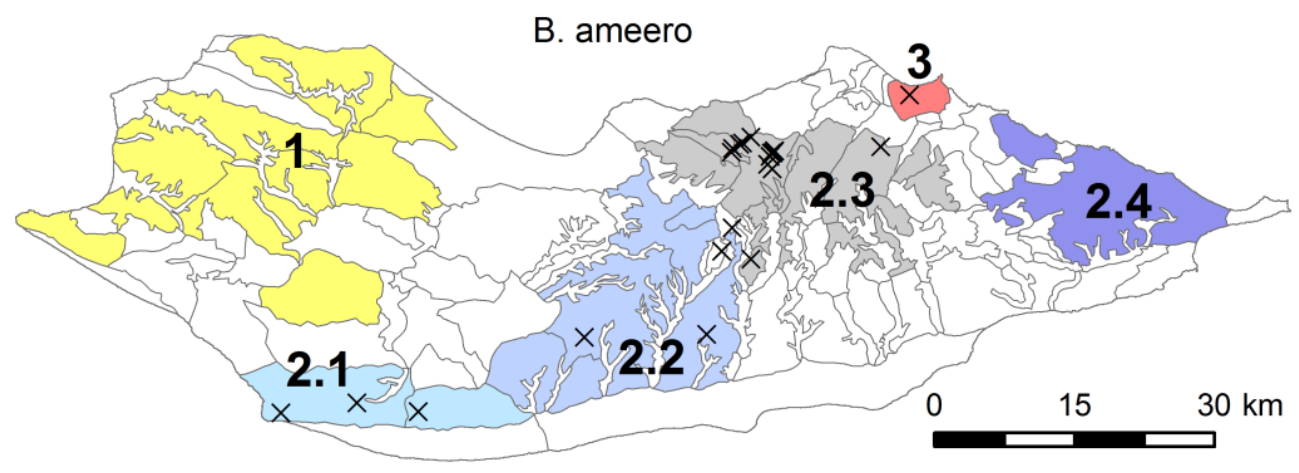

1 B. ameero from the Western Plains Bioregion, 2.1 B. ameero from the Quatariyah mountains

2.2 B. ameero from the Shibehon area, 2.3 B. ameero from the Haggeher mountains and the Diksam area

2.4 B. ameero from the Momi area, 3 B. ameero from the Bit gobihir massif 
Fig. 2: Map of Boswellia bullata seed areas

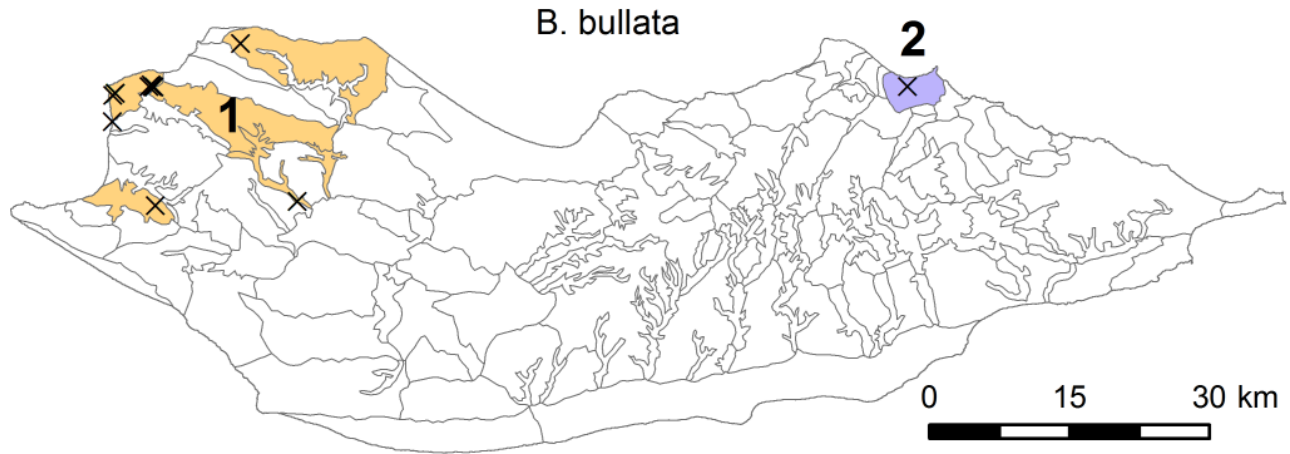

1 B. bullata from the Western Plains Bioregion, 2 B. bullata from the Bit gobihir massif

\section{Fig. 3: Map of Boswellia dioscorides seed areas}

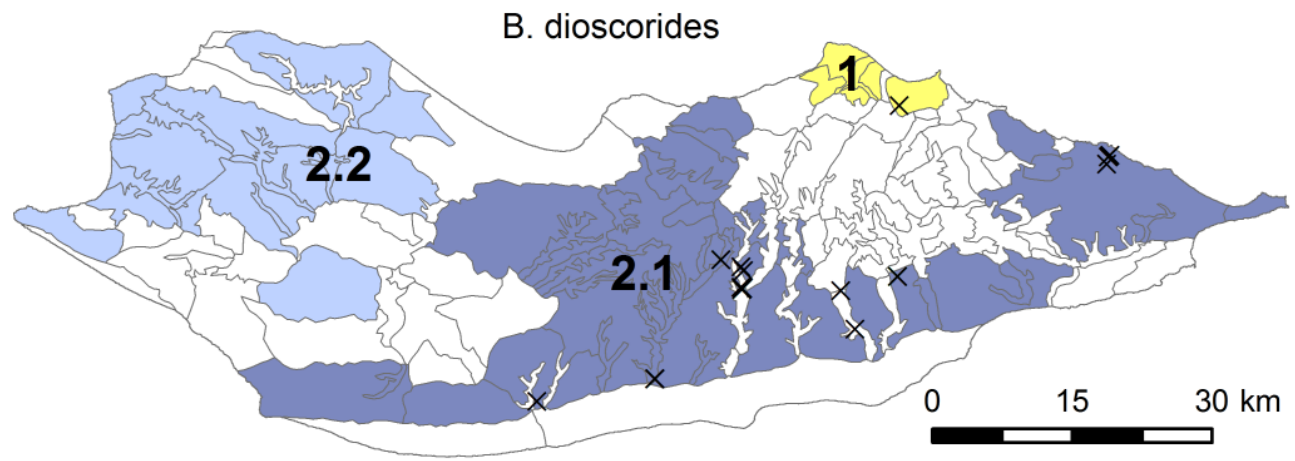

1 B. dioscorides from the Bit gobihir massif,

2.1 B. dioscorides from the Southern Plains Bioregion, 2.2 B. dioscorides from the Western Plains Bioregion (without an actual occurence)

Fig. 4: Map of Boswellia elongata seed areas

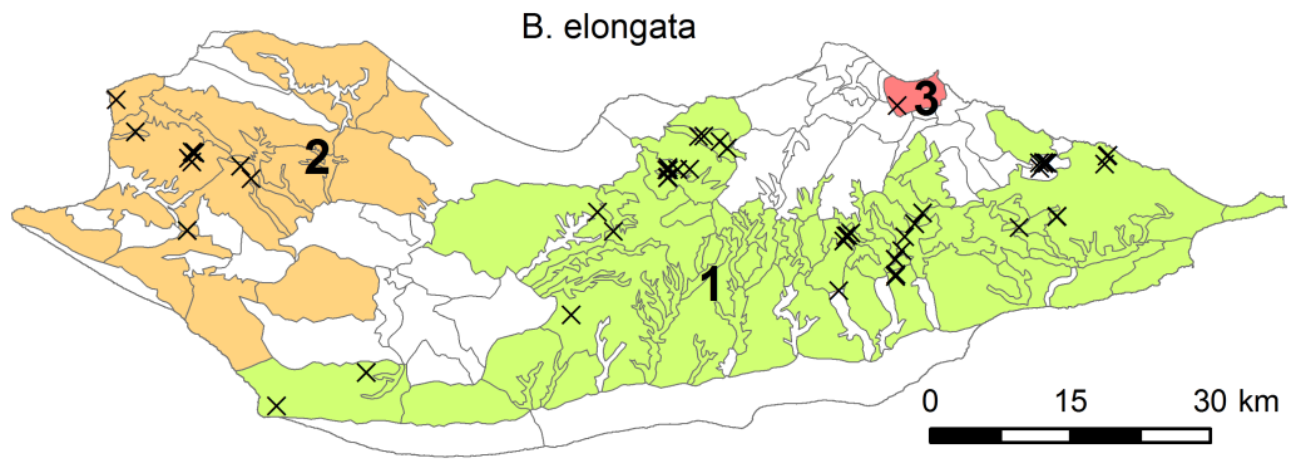

1. B. elongata form the Southern Plains Bioregion, 2. B. elongata form the Western Plains Bioregion

3. B. elongata form the North Plains Bioregion 


\section{Fig. 5: Map of Boswellia nana seed areas}

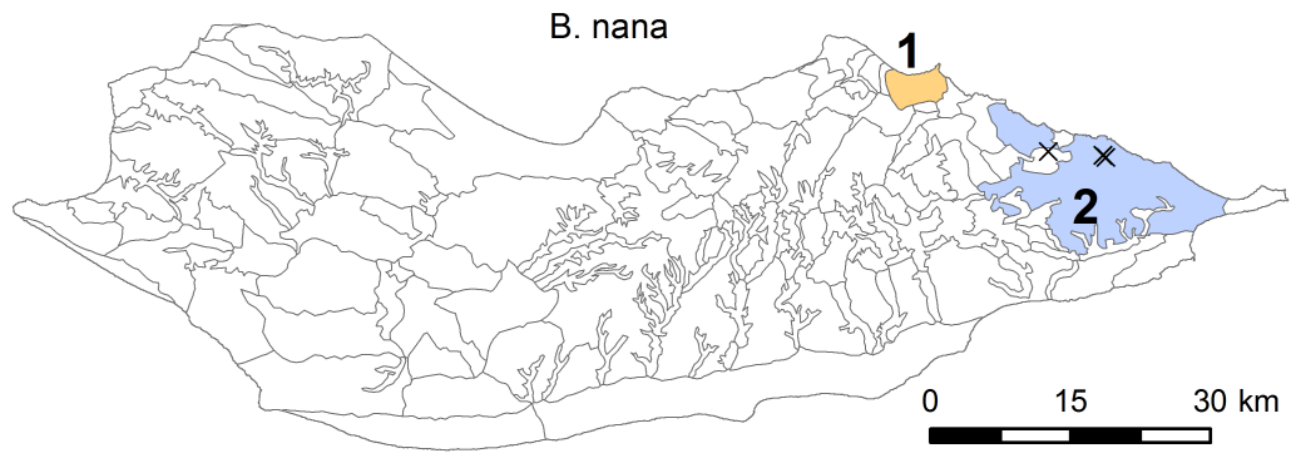

1. B. nana from the Bit gobihir massif, 2. B. nana from the Hamadero massif

Fig. 6: Map of Boswellia popoviana seed areas

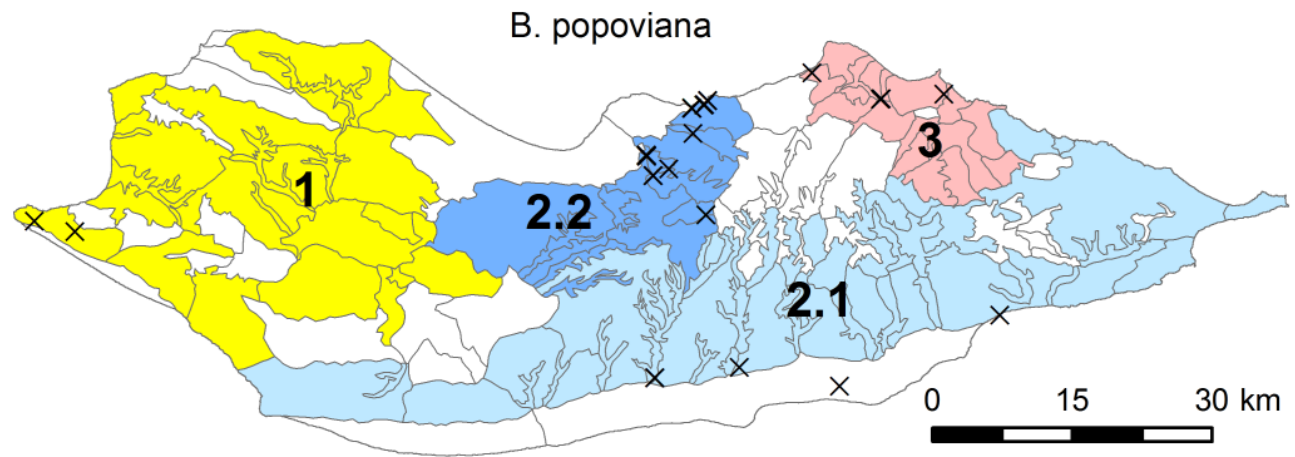

1. B. popoviana from the Western Plains Bioregion, 2.1 B. popoviana from the Southern Plains Bioregion, 2.2. B. popoviana from northwestern part of the Southern Plains Bioregion, 3. B. popoviana from the North Plains Bioregion

Fig. 7: Map of Boswellia socotrana seed areas

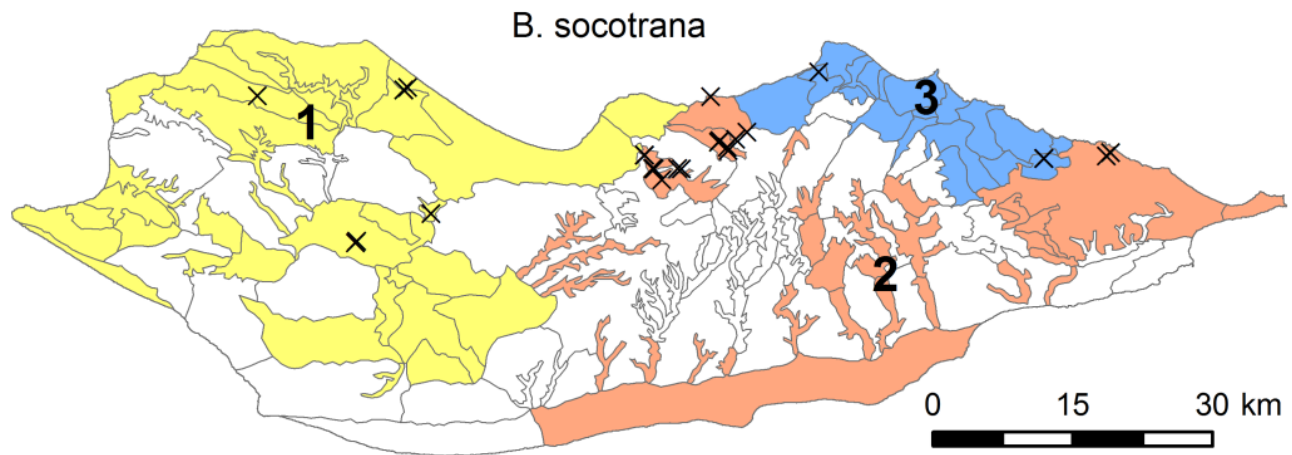

1 B. socotrana grey-leaved from the Western Plains Bioregion

2 B. socotrana grey-leaved nad green-leaved from the Southern Plains Bioregion

3 B. socotrana grey-leaved nad green-leaved from the North Plains Bioregion 


\section{DISCUSSION}

\section{Interpretation of maps}

The creation of the models of potential areas of Boswellia on Socotra is very problematic. This is due to the great diversity of the relief, the geological subsoil heterogeneity, the influence of the mist and dew on the distribution of Boswellia (Mies, 2001; Brown \& Mies, 2012) and far-reaching vegetation changes, as well as a strong reduction of actual areas of distribution as a result of human activities. The occurence of the mist and dew, and their direct influence on the expansion of Boswelia, is difficult to monitor in conditions on Socotra; no particular data have been published so far, nor have they been taken into account in the published model of potential areas of Boswellia.

The above-mentioned facts are probably the reason why the localities of the $B$. ameero species were discovered during the field survey (Miller et al., 2004), that occur outside the potential area. The potential areas published (Attore et al., 2011) are therefore unlikely to be comletely accurate; however, they are the only published models available for the creaton of seed regions of Boswellia.

Similarly, the maps of seed regions presented here unfortunately have to be considered only as a schematic representation of the real situation, being applicable only at the landscape scale. The area of depicted seed regions is greater than actual and potential areas of distribution. This is due to the lack of accurate input data, and therefore it was necessary to include the entire orographic regions within the seed regions, even if the real or potential area occupies only a small part of the orographic region. Allocated seed regions can then be considered to be orographic units, in which parts (often only marginal) the species of Boswellia may theoretically occur. Extending the seed regions to other areas, outside the models of potential areas, is justified also by the fact that Boswellia were found beyond the modelled potential area (Attore et al., 2011), during field survey as well as in pubication (Miller et al., 2004).

Specific plantings in allocated seed regions, evidently, should not be carried out randomly, but only after a careful consideration, in habitats fulfilling the ecological requirements for the survival of the species. The values measured in localities with an upto-date occurence of individual species of Boswellia, published in (Attore et al., 2011), can serve as an example (Král \& Pavliš, 2006). Especially for terrestrial species, it would be more practical to choose locations suitable for the plantation on the basis of occurence of plant communities, in which the given species of Boswellia occur naturally (Habrová, 2004; Kürschner et al., 2006; De Sanctis et al., 2013).

For the selection of the habibtats suitable for the plantation, it is also necesary to deal with the question, whether the Boswellia really occurred throughout its potential area. Taking into account the current level of degradation of vegetation due to human activities, strongly fragmented and over-aged populations of Boswellia, it is very probable that the areas of Boswellia, especially the terrestrial ones, were considerably larger in the past. To confirm of the assumption that the potential areas are largely identical to the area in which the Boswellia historically grew, it would serve to compare the localities previously used to build the models of potential areas (so-called used populations) (Attore et al., 2011) and other known localities (so-called known localities). An overwhelming majority of "known populations" occurs within the modelled potential area, even if these are situated in other (often isolated) parts of the potential area than the "used populations" are.

A subject for further discussion is: which seed region has the best genetic material for plantings in localities where the original population is already extinct, or, whether to carry 
on any reintroduction. Primarily, it is certainly preferable to focus on strengthening existing populations.

\section{Distribution and status of the populations}

The results show that most species of Boswellia on Socotra do not form a homogeneous population throughout their area. Rather, they are variable and form morphologically or geographically separate subpopulations. The detailed results of the morphological study will by published later.

The information on the age structure of populations of Boswellia is very limited and based only on indirect observations (Attore et al., 2011). The average longevity of Boswellia species is also unknown. Direct measurements, such as counting tree-rings of living trees, is not feasible for obvious reasons.

There is no published information on the process of the production of wood cells by the medium of the vascular cambium within Boswellias of Socotra; therefore, we do not know with certainty what time period corresponds to one tree-ring. Therefore, it is very difficult to also determine the age of deceased individuals. That is why, at present, the best way to characterise the age structure of populations is through the use of indirect indicators, such as BHD (Attore et al., 2011). Despite the lack of accurate data from available literary sources and from field observation itself, it is clear that without taking effective steps in the near future, there will be at least in some species a significant population decline, and even a possible extinction.

The survival of the species, as well as the maintenance of a high intraspecific variability, is undoubtedly one of the priorities of nature conservation. It is therefore necessary to establish rules and procedures for the reproduction of vegetation, that will prevent the loss of biodiversity.

\section{Possibilities of populations reproduction}

We can support the reproduction of vegetaion, for example, with individual protection for spontaneously germinated seedlings against grazing, by a fencing medium. This procedure, from the point of view of biodiversity conservation, is obviously ideal; on the other hand, the individual protection of seedlings is laborious and expensive. Besides, on Socotra it is difficult to accomplish, since there is a nontransparent system of land ownership; and if there is a barrier against the grazing installed on one person's land, without the permission of the land owner (and financial reward), this barrier is very often removed by resident herdsmen. Along with the individual protection it is therefore necessary to use the forest nurseries as well, as they are used in the forest regeneration in the Czech Republic. A system of home gardens can be used as an effective means for the regeneration of individual trees (Ceccolini, 2002).

It is necessary to especially observe the following rules:

1 - To plant seedlings only within the seed region or sub-region, from which the seed originates. In justified cases and after careful consideration, it is possible to trasfer the seedlings to other sub-regions of the area as well, or, in the case of a disappearance of the original population, to other seed regions.

2 - Not to plant seedlings within the areas, where the species probably did not occur in the past, e.g. outside the allocated potential area (Attore et al., 2011). 
3 - To cultivate seedlings in advance within fenced forest nurseries from seeds preferentially, because this reduces the probability of the distribution of certain pathogens, especially plant viruses and fungi, and maintains genetic diversity. It also eliminates the negative impact on the vitality of existing populations as a consequence of the taking of cuttings for vegetative propagation. Hereafter, it is advisable to remove the seeds from a larger number of trees. The fruits of Boswellia are capsules, from which the mature seeds drop out; obtaining the mature seeds is therefore relatively difficult. In order to streamline the seed collection, it is possible, for example, to envelop the immature infructescence into a fine mesh, preventing the drop-out and the distribution of the seeds in the locality. Another option is to collect and to nurse the seedlings, originating from the natural regeneration that occurs during the winter rainy season and which would be quickly devastated by grazing without fencing anyway.

5 - To plant only healthy seedlings without any evident pest or pathogen attack.

6 - To plant the seedlings of optimal size. The exact determination of the ideal size of seedlings suitable for nurseries, that use standardised silvicultural techniques, and, requires relatively difficult field experiments. In conditions of Socotra, it is therefore preferable to estimate the ideal size only, taking into account especially the following factors. Bigger seedling requires the protection from grazing for a shorter period. Conversely, if the seedling grows in an insufficiently large container, the root system will be deformed, which will become evident by reduced vitality of the individual (Kriegel, 1990). Besides, the transplantation of large seedlings requires an additional watering, even when the planting is performed within the correct time limit.

7 - To plant the seedlings at the beginning of the wet season, if irrigation is not assured.

8 - To protect the seedlings from grazing, at least until they reach a height of $150 \mathrm{~cm}$.

9 - To avoid the replacement of seedlings from different seed regions, it is necessary to label the origin of seedlings. The seedlings are designated by 2 first letters from species name and 2 numbers separated by a hyphen: the first number indicates the seed region and the second one the sowing year. For example, designation BU 5-2013 means that it is a seedling B.bullata from the Bit gobihir, the 2013 is sowing year. Each number is affixed to the seedling itself in an appropriate manner.

\section{CONCLUSiON}

The maps of 19 seed regions and 8 sub-regions were created by the methods described above. These maps and proposed rules of reproduction can be used when planning the planting of the Boswellia, and can help to minimise the risk of loss of biodiversity. It is a matter of further discussion, how and whether to continueplanting within the isolated areas, where the potential range of some species extends to, where, simultaneously, there are no living Boswellia available as an autochthonous reproductive material. The proposed procedure can also be applied to other endemic tree species growing on the island.

\section{ACKNOWLEDGEMENT}

The article was published thanks to support from the Ministry of Education of the Czech Republic (project LANDTEAM, reg. No. CZ.1.07/2.3.00/20.0004). 


\section{REFERENCES}

Attore, F., Francesconi, F., Taleb, N., Scholte, P., Saed, A., Alfo, M. \& Bruno, F., (2007). Will dragonblood survive the next period of climate change? Current and future potential distribution of Dracaena cinnabari (Socotra, Yemen). Biological Conversation. 138 (3-4), pp. 430-439.

Attorre, F., Taleb, N., De Sanctis, M., Farcomeni, A., Guillet, A. \&Vitale M., (2011). Developing conservation strategies for endemic tree species when faced with time and data constraints: Boswellia spp. on Socotra (Yemen). Biodiversity Conservation, 20 (7), pp. 1483-1499.

Batelka, J., (2013). Socotra Archipelago - a lifeboat in the sea of changes: advancement in Socotra insect biodiversity survey. Acta entomologica Musei nationalis Pragae, 52 (2), pp. 1-26.

Brown, G. \& Mies, B., (2012). Vegetation ecology of Socotra. Plant and Vegetation 7: Springers.

Ceccolini, L., (2002). The homegardens of Soqotra island, Yemen: an example of agroforestry approach to multiple land-use in an isolated location. Agroforestry Systems (56), pp. 107-115.

Cheung, C. \& Devantier, L., (2006). Socotra - A Natural History of the Island and their People. Hong Kong: Oddysey Books and Guides, Airphoto International Ltd.

Culek, M., (2004). Biogeografické a orografické členění souostroví Sokotry. In Pavliš, J. \& Habrová, H. (eds.), Závěrečná zpráva o výsledcich řšsení projektu v letech 2002 až 2004 "Tvorba ekologické sitě, agrolesnická, kulturní a výchovná východiska trvale udržitelného rozvoje ostrova Sokotra”, část B: Agrolesnictví a ekologická sit' (pp. 40-46). Brno: MZLU Brno.

Daly, D.C., Harley M.M., Martínez-Habibe, M.C. \& Weeks, A., (2011). Burseraceae. In. Kubitzky, K. (Ed.), The families and genera of vascular plants: Sapindales, Cucurbitales, Myrtaceae, (pp. 76-104), Vol. 10, Berlin: Springer.

De Sanctis, M., Adeeb, A., Farcomeni, A., Patriarca, Ch., Saed A. \& Attorre, F., (2012). Classification and distribution patterns of plant communities on Socotra Island, Yemen. Applied Vegetation Science 16, 148-165. Doi: 10.1111/j.1654-109X.2012.01212.x

Eslamieh, J., (2011). Cultivation of Boswellia Sacred Trees of Frankincense. USA: A Book's Mind.

Habrova, H., (2004). Geobiocoenological differentiation as a tool for sustainable land-use of Soqotra Island (Republic of Yemen). Ekológia Bratislava. 23 (1), pp. 47-57. ISSN 1335-342X.

Habrová, H., (2012). Twelve years of native-tree planting on Soqotra. Tayf - The Soqotra Newsletter. 9, 12. ISSN 0000-0000.

Habrová, H. \& Němec, P., 2013. New Czech Development Assistance Project on Soqotra: Support of small-scale farmers and agricultural education on Soqotra Island. TAYF The Soquorta Newsletter. 10, 3.

Kilian, N. \& Hubaishan, M.A., (2006). Biodiversity of Socotra: forests, woodlands and bryophytes. Englera. 28, pp. 11-55. ISBN: 3921800617.

Kilian, N. \& Hein, P., (2006). New and noteworthy records for the v ascular plant flora of Socotra Island, Yemen. Englera. 28, pp. 57-78. ISBN: 3921800617. 
Kral, K. \& Pavlis, J., (2006). The first detailed land cover map of Socotra Island by Landsat /ETM+ data. Int. Journal of Remote Sensing. 27 (15), pp. 3239-3250.

Kriegel, H., (1990). Growth and development of Scots pine plantations with deformed roots. Zprávy Lesnického Výzkumu 35 (1), pp. 17-20. ISSN 0322-9688.

Kruckeberg, A. \& Rabinowitz, D., (1985). Biological aspects of Endemism in higher plants. Annual Review of Ecology and Systematic. 16, pp. 447-97.

Kürschner, H., Hein, P., Kilian, N. \& Hubaishan, M.A., (2006). Diversity and zonation of the forests and woodlands of the mountains of northern Socotra, Yemen. Englera. 28, pp. 11-55. ISBN: 3921800617.

Mies, B., (2001). Flora und Vegetationsokologie der Insel Soqotra. Essener Okologische Schriften 15.

Miller, A. G., Morris, M., Diccon, A. \& Atkinson, R., (2004). Ethnoflora of the Soqotra Archipelago. Royal Botanic Garden Edinburgh. ISBN 1-872291-59-7.

Ministerstvo zemědělství české republiky, (1996). Zákon o lesích a př́slušné vyhlášky: Agrospoj Praha.

Scholte, P. \& De Geest, P., (2010). The climate of Socotra Island (Yemen): A first-time assessment of the timing of the monsoon wind reversal and its influence on precipitation and vegetation patterns. Journal of Arid Environments. 74 (11), pp. 1507-1515.

Scholte, P., Al-Okaishi, A. \& Suleyman, A.S., (2011). When conservation precedes development: A case study of the opening up of the Socotra archipelago, Yemen. ORYX. 45(3), pp. 401-410.

Van Damme, K. \& Banfield, L., (2011). Past and present human impacts on the biodiversity of Socotra Island (Yemen): implications for future Conservation. Biodiversity Conservation in the Arabian Peninsula Zoology in the Middle East. 3, pp. 31-88. ISSN 0939-7140.

Weeks, A., Daly, D.C. \& Simpson, B.B., (2005). The phylogenetic history and biogeography of the frankincense and myrrh family (Burseraceae) based on nuclear and chloroplast sequence data. Molecular Phylogenetics and Evolution. 35(1), pp. 85-101. DOI:10.1016/j.ympev.2004.12.021. 